\title{
Identification of a novel lytic peptide for the treatment of solid tumours
}

\author{
Claudia Szczepanski ${ }^{1}$, Olav Tenstad ${ }^{3}$, Anne Baumann ${ }^{4}$, Aurora Martinez ${ }^{4}$, Reidar \\ Myklebust $^{1}$, Rolf Bjerkvig ${ }^{1,2, *}$, and Lars Prestegarden ${ }^{1,5, *}$ \\ ${ }^{1}$ NorLux Neuro-Oncology, Dept. of Biomedicine, University of Bergen, Norway \\ ${ }^{2}$ Centre de Recherche Public de la Santé, Luxembourg, Luxemburg \\ ${ }^{3}$ Cardiovascular Research Group, Dept. of Biomedicine, University of Bergen, Norway \\ ${ }^{4}$ Biorecognition Group, Dept. of Biomedicine, University of Bergen, Norway \\ ${ }^{5}$ Dept. of Dermatology, Haukeland University Hospital, Bergen, Norway \\ * These authors contributed equally \\ Correspondence to: Lars Prestegarden, email: Lars.Prestegarden@biomed.vib.no
}

Keywords: Antimicrobal lytic peptides, cationic lytic peptides, cancer treatment, membrane disruption.

Received: April 16, $2014 \quad$ Accepted: June 26, 2014

Published: June 27, 2014

This is an open-access article distributed under the terms of the Creative Commons Attribution License, which permits unrestricted use, distribution, and reproduction in any medium, provided the original author and source are credited.

\section{ABSTRACT:}

Originally known as host defence peptides for their substantial bacteriotoxic effects, many cationic antimicrobial peptides also exhibit a potent cytotoxic activity against cancer cells. Their mode of action is characterized mostly by electrostatic interactions with the plasma membrane, leading to membrane disruption and rapid necrotic cell death.

In this work, we have designed a novel cationic peptide of 27 amino acids (Cypep-1), which shows efficacy against a number of cancer cell types, both in vitro and in vivo, while normal human fibroblasts were significantly less affected. Surface plasmon resonance experiments as well as liposome leakage assays monitored by fluorescence spectroscopy revealed a substantial binding affinity of Cypep-1 to negatively charged liposomes and induced significant leakage of liposome content after exposure to the peptide. The observed membranolytic effect of Cypep-1 was confirmed by scanning electron microscopy (SEM) as well as by time-lapse confocal microscopy. Pharmacokinetic profiling of Cypep-1 in rats showed a short plasma half-life after i.v. injection, followed mainly by retention in the liver, spleen and kidneys. Extremely low concentrations within the organs of the central nervous system indicated that Cypep-1 did not pass the blood-brain-barrier.

Local treatment of 4T1 murine mammary carcinoma allografts by means of a single local bolus injection of Cypep-1 led to a significant reduction of tumour growth in the following weeks and prolonged survival. Detailed histological analysis of the treated tumours revealed large areas of necrosis.

In sum, our findings show that the novel cationic peptide Cypep-1 displays a strong cytolytic activity against cancer cells both in vitro and in vivo and thus holds a substantial therapeutic potential.

\section{INTRODUCTION}

Naturally occurring antimicrobial peptides (AMPs) represent a first-line defence of eukaryotic cells against bacteria, protozoa, fungi and viruses [1-3]. Originally known as host defence peptides [4] or defensines [5], many AMPs, as well as their synthetic variants, have been found to exert a broad spectrum of antimicrobial and anticancer effects, while often affecting normal mammalian cells to a far lesser extent [6-14].

These cytolytic effects of AMPs are largely 
attributed to their cationic nature $[15,16]$, leading to electrostatic interactions with negatively charged cell membranes [17]. AMPs may either cause plasma membrane destabilization or cell lysis, which leads to rapid necrotic cell death. Alternatively, some AMPs permeate the cell membrane and then destabilize or disrupt the target cell's mitochondrial membranes instead, resulting in a pro-apoptic effect [18-20]. In addition, a few AMPs have been found to inhibit angiogenesis [11, 13, 20, 21]. Since their lytic potential is neither receptor-mediated nor dependent on the cellular replication cycle, AMPs targets multi-drug-resistant cancer cells successfully and thus represent a promising group of novel oncolytic treatment agents [12, 19, 22-25].

Normal mammalian cells are known for their asymmetric distribution of electrostatically neutral zwitterionic phospholipids within their membrane bilayer [26]. Their outer membrane leaflets consist mainly of cholinophospholipids with neutral polar head-groups, while the aminophospholipids with negatively charged headgroups, such as phosphatidylethanolamine (PE) and phosphatidylserine (PS) are mainly found in their inner membrane leaflets [27]. This asymmetrical lipid arrangement is thought to promote mechanical membrane stability, whereby especially interactions between the PS on the inner leaflet and skeletal proteins seem to entail membrane modulatory effects [28].

In contrast, neoplastic cells often overexpress PS in the outer leaflet of their cell membranes [12, 16, 25, 29-34], resulting in a slightly more negatively charged membrane than normal cells. This promotes the interaction with AMPs and may therefore be partly responsible for the relative tumour cell selectivity [11]. Additional membrane surface characteristics of malignant cells, such as a lowered cholesterol content [36-38], alterations in the glycolysation of membrane-associated glycoproteins and glycolipids, [39-42] and the expression of certain surface proteoglycans [14, 43-46] as well as the presence of filopodia and microvilli [47] may, in addition, enhance the susceptibility of tumour cells towards AMPs.

In this work, we designed a library of 96 peptides with potential anti-tumour activity in silico. These peptides were originally derived from active sites of known tumour suppressors and oncogenes, as part of an attempt to identify specific peptides that might restore the function of inactivated tumour suppressors or interfere with oncogenes by competitive inhibition. The resulting molecules were synthesized and screened on monolayer cultures of the U87 human glioma cell line. While three out of the 96 peptides displayed anti-tumoural properties in vitro, we decided to focus on the most potent peptide. This peptide was originally derived from the tumour suppressor Axin2 (aa 126-140), which is a central protein in the Beta-Catenin pathway. However, instead of mimicking the functions of Axin2, we found it to have a lytic effect on the plasma membrane of cancer cells.
To avoid proteolytic degradation in vivo, we substituted the naturally occurring L-amino acids of the original in silico formula with their D-amino acid enantiomeres, as these are not recognized by serum proteases [48-50]. This resulted in a stable cationic peptide of 27 D-amino acids, designated Cypep-1, with a theoretical isoelectric point (pI) of 11.81 and a molecular weight of $3492.16 \mathrm{U}$ [51].

We then proceeded to evaluate the efficacy of Cypep-1 on a total of 17 cell lines in vitro (4 osteosarcoma, 6 glioma and 3 mammary carcinoma) as well as 3 normal human cell lines ( 2 fibroblast cell lines and normal human osteoblasts). In addition, we assessed the cytotoxic effect of the peptide on 4T1 murine mammary carcinoma cells in vitro, as well as on corresponding allografts in vivo. The observed membranolytic effect of Cypep-1 was confirmed by scanning electron microscopy (SEM) as well as timelapse confocal microscopy. Structural and mechanistic insights on the interaction of Cypep-1 with biological model membranes were obtained by surface plasmon resonance (SPR) and liposome-content leakage assays monitored by fluorescence spectroscopy. Furthermore, the pharmacokinetic profile of Cypep-1, its in vivo toxicity and mode of action were delineated.

\section{RESULTS}

\section{Peptide Design and Screening}

The initial screening of the peptide library on U87 glioma cells showed that three out of the 96 peptides designed in silico had a significant cytotoxic effect. The most potent peptide was selected for further development (Suppl. Fig.1, upper panel).

We then compared the anti-tumour efficacy of the original peptide formula (all L-amino acids) to the two sub-variants: D-aa (ri) and D-aa by testing them in various concentrations on U87 cells. Crystal violet staining showed that, while all three peptide formulations had a cytotoxic effect, the formulations made of D-amino acids proved to be more potent than the parent L- amino acid formula (Suppl. Fig.1, middle panel). The superior antitumour activity of the D-aa variant was verified by light microscopy. This showed that the monolayer of a U87 cell line had contracted considerably after 3 hours exposure and extensive cell loss was observed (Suppl. Fig.1, lower panel).

\section{Scanning Electron Microscopy (SEM)}

At a magnification of 1000x, the scanning electron micrographs of untreated 4T1 mammary carcinoma cells showed cells with a flattened morphology, featuring membrane ruffles and filopodia (Fig. 1A). A more detailed 
micrograph at 3000x revealed small microvilli protruding from an intact cell membrane (Fig. 1B).

The first signs of cell membrane destruction became apparent after 60 minutes incubation with $35 \mu \mathrm{g}$ Cypep-1/ml, (Fig. 1C), whereby numerous holes in the plasma membrane appeared (arrows in Fig. 1D). SEM micrographs taken after 6 hours exposure revealed a total disintegration of the plasma membrane (Fig. 1E and F).

\section{Cell Viability Assays}

\section{MTT Viability Assays}

The cytotoxic effects in vitro of Cypep-1 clearly showed a dose and time dependent response for all cell lines (Fig. 2). As seen in Fig. 2B (lower panel), the average surviving fractions after $60 \mathrm{~min}$ of incubation with $20 \mu \mathrm{g}$ Cypep- $1 / \mathrm{ml}$ varied between 7\% (mammary carcinoma AU 565; most sensitive cell line) and 33\% (glioblastoma GaMg; least sensitive cell line). The two normal cell lines were significantly less affected in comparison, showing survival rates of $66 \%(\mathrm{HFF} 1)$ and $44 \%$ (HOB). On

\section{Scanning Electron Microscopy}
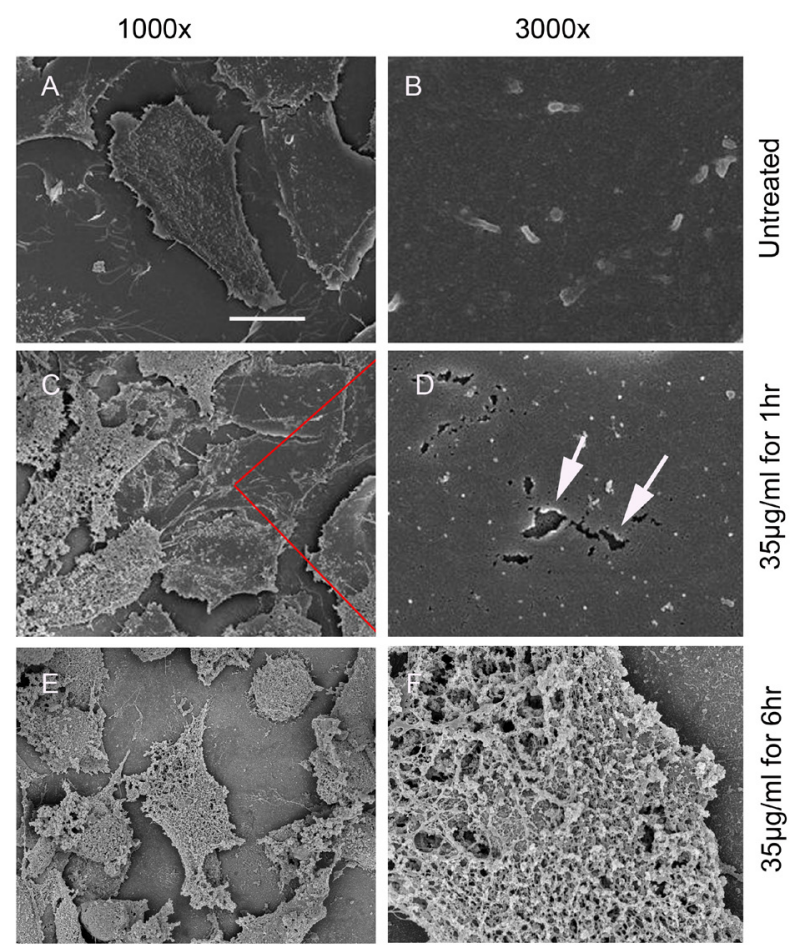

Figure 1: Scanning electron micrograph (SEM) of the mammary carcinoma cell line 4T1 demonstrates disintegration of the plasma cell membrane after treatment with Cypep-1. A-B) Untreated cells. C-D) After 1 hour incubation E-F) After 6 hours incubation. average, all cancer cell lines showed significantly lower surviving fractions $(18.6 \%)$ than the normal human cell lines $(56 \%)$ after 60 min exposure to Cypep- 1 .

\section{LIVE/DEAD Assay}

Visible cytotoxic effects on the osteosarcoma cell lines (U2OS, SaOs2) could already be observed after 3 hours incubation time with $10 \mu \mathrm{g}$ Cypep-1/ml (Fig. 3A and B), which swiftly increased with higher peptide concentrations. Normal human fibroblasts $(142 \mathrm{Br}$, HFF1) were again significantly less affected $(\mathrm{p}<0.0001)$, displaying the first signs of cytotoxicity at an elevated concentration of $25 \mu \mathrm{g}$ Cypep-1/ml. According to morphometric evaluation (Fig.3B), the average surviving fractions of the osteosarcoma cell lines were lower than $5 \%$ after exposure to a maximum concentration of $35 \mu \mathrm{g}$ Cypep- $1 / \mathrm{ml}$, while the viability for the corresponding fibroblast cell lines $142 \mathrm{Br}$ and HFF1 was $81 \%$ and $64 \%$, respectively.

\section{Time Lapse Confocal Microscopy}

To monitor the kinetics of Cypep-1 in vitro, timelapse confocal microscopy was performed on monolayers of 4T1 murine mammary carcinoma cells incubated with $20 \mu \mathrm{g}$ Cypep-1/ml for 3 hours. As shown in Fig. 3C (upper panel), the induced membrane disruption caused an extensive loss of cell content into the medium, the strongest effect occurring between 40 and 55 min (Suppl. Film 1). To further visualize this effect, the experiment was repeated with stably transfected dsRed 4T1 cells, exposing them to the same peptide concentration and incubation period. A sequential, but immediate leakage of dsRed was observed between 40 and $45 \mathrm{~min}$, as well as between 50 and 55 min of exposure time to Cypep-1, indicating membrane destruction (arrows in Fig. 3C; Suppl. Film 2).

\section{Functional Interactions with Biological Model Membranes}

Further insights on the interaction of Cypep-1 with biological model membranes were obtained by SPR as well as liposome-content leakage assays monitored by fluorescence spectroscopy.

\section{Surface Plasmon Resonance (SPR) Experiments}

As shown in Fig. 4A, SPR revealed that Cypep-1 bound to both the negatively charged (PBPS: EYL) as well as neutral (EYL) liposomes. From the curve fittings of the data shown in Figure 4A, the peptide concentration of half-maximal binding $\left(\mathrm{S}_{0.5}\right)$, a measure of the inverse of 
the apparent association or partition constant $\left(1 / \mathrm{K}_{\mathrm{a}}\right.$ (app)), was calculated to provide a comparative and operational measurement for affinity. The resulting $\mathrm{S}_{0.5}$ values showed that Cypep-1 bound with significantly higher affinity to the negatively charged PBPS: EYL liposomes $\left(\mathrm{S}_{0.5}=\right.$ $16.2 \pm 4.4 \mu \mathrm{g} / \mathrm{ml}(4.7 \pm 1.0 \mu \mathrm{M}))$ than to the neutral EYL liposomes $\left(\mathrm{S}_{0.5}=39.1 \pm 5.3 \mu \mathrm{g} / \mathrm{ml}(11.3 \pm 1.5 \mu \mathrm{M})\right)$.

A

Glioma cell lines
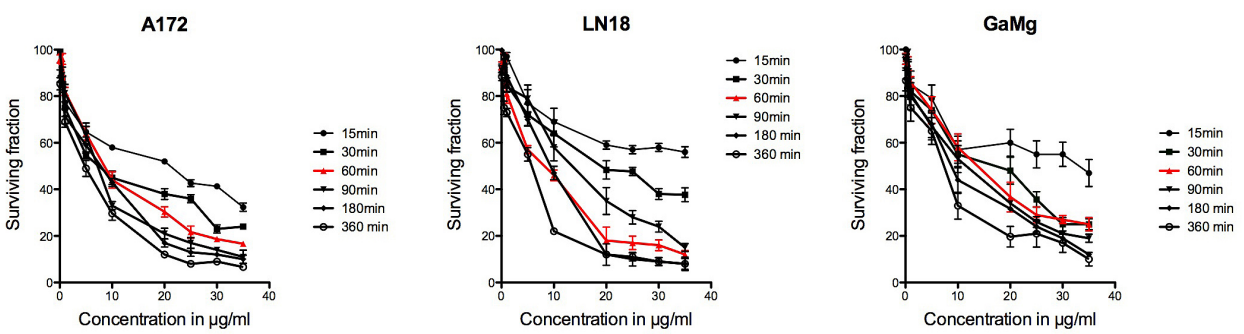

Osteosarcoma cell lines
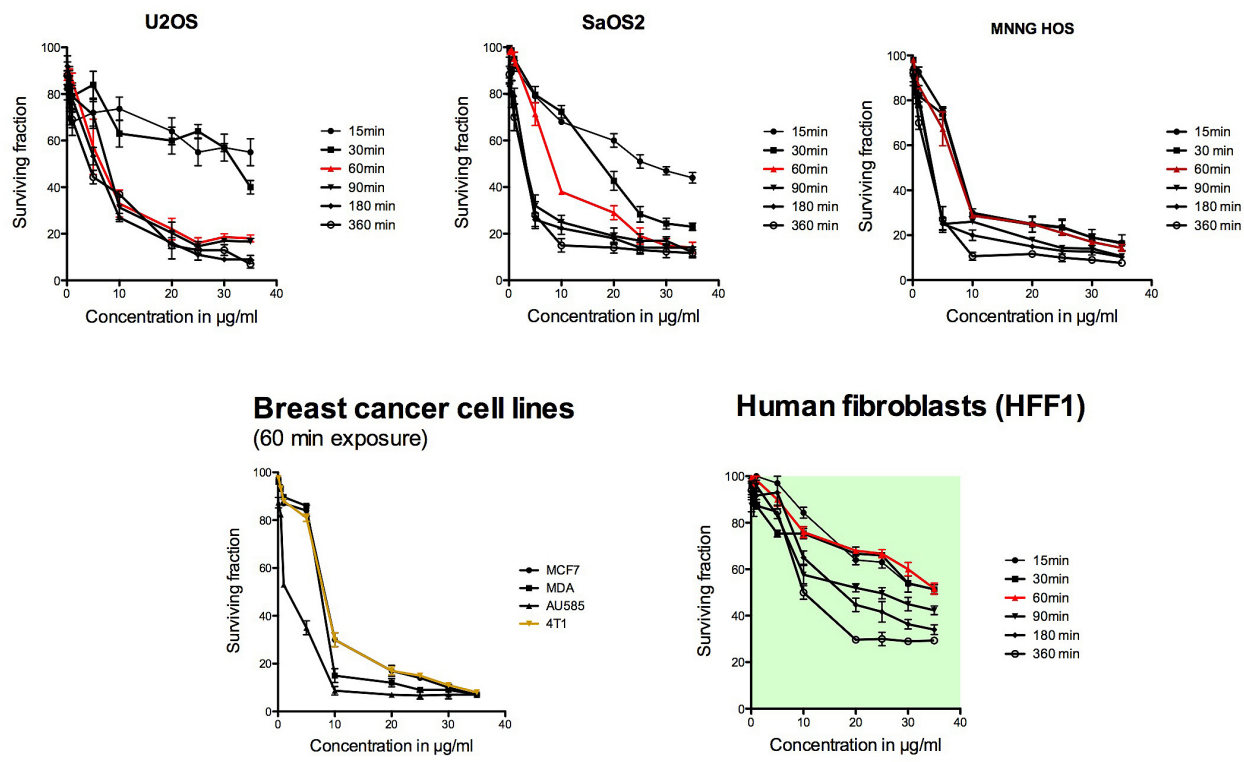

Human fibroblasts (HFF1)
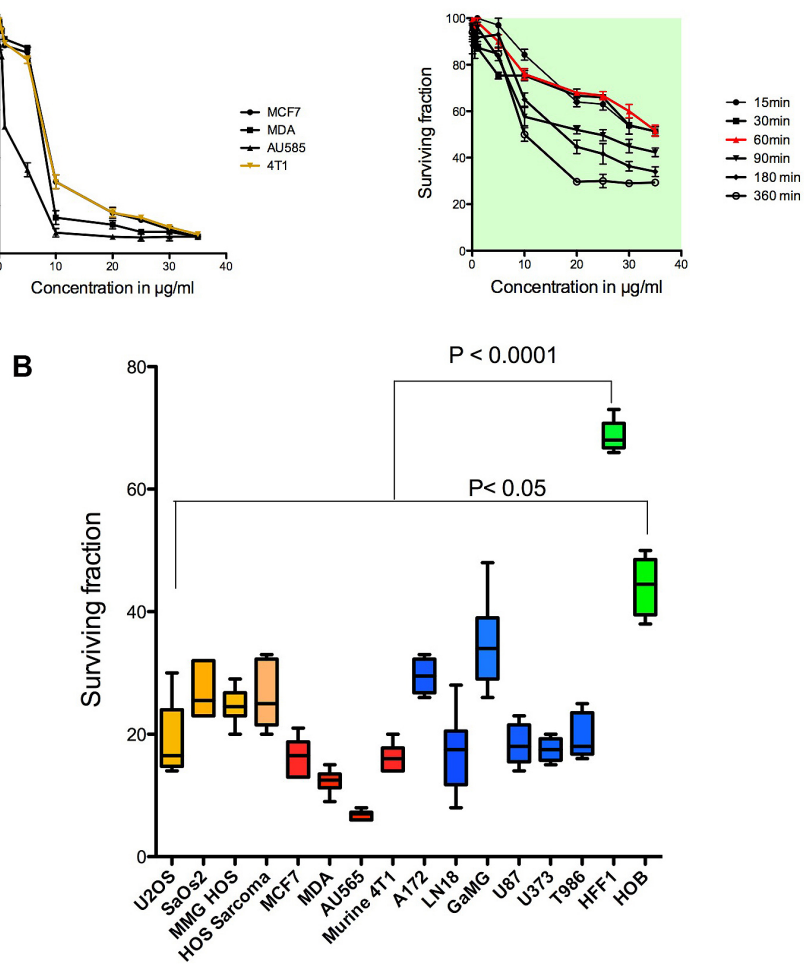

Figure 2: A) Dose and time dependent effect of Cypep-1 on different cancer cell lines and normal fibroblasts. B) Surviving fraction of the osteosarcoma (orange), breast cancer (red) and glioma cell lines (blue) after 60min. exposure to 20 $\mu \mathrm{g} / \mathrm{ml}$ Cypep- 1 . Green bars represent two normal cell lines HFF1 and HOB. 


\section{Liposome Leakage Assays}

The release of the fluorophore content from the respective liposomes in the presence of Cypep-1 and the control peptide (Peptide A) is depicted in Fig. 4B. A significant leakage of ANTS was observed for both types of liposomes in the presence of Cypep-1. At the intermediate concentrations tested (30-70 $\mu \mathrm{g}$ Cypep-1/ml dist. $\mathrm{H}_{2} \mathrm{O}$ ), the negatively charged PBPS: EYL liposomes were clearly more affected by Cypep-1 than the neutral EYL liposomes. However, a similar extent of release was obtained for both liposome types at the maximum concentration $(90 \mu \mathrm{g}$ Cypep- $1 / \mathrm{ml})$. In both cases, the leakage upon exposure to Cypep-1 occurred in a dose dependent manner. Basically no change in fluorescence was observed in either of the liposome mixtures when exposed to the control peptide.
The $\mathrm{S}_{0.5}$ value provides an estimation of Cypep-1 concentration needed for half-maximal binding. No satisfactory estimation of $\mathrm{S}_{0.5}$ could be obtained for the disruption of neutral EYL liposomes by Cypep 1 due to lack of saturation at attainable peptide concentrations. Nevertheless the measurements clearly indicated a higher affinity of Cypep-1 towards the negatively charged PBPS: EYL liposomes than towards the neutral ones.

Comparing the binding (Fig. 4A) and disruption measurements (Fig. 4B), the concentration of Cypep-1 necessary to achieve membrane disruption in negatively charged vesicles (Fig. 4B; $\mathrm{S}_{0.5}=8.3 \pm 0.5 \mu \mathrm{M}$ ) was about two fold higher than the concentration required for halfmaximal binding (Fig. 4A; $\mathrm{S}_{0.5}=4.7 \pm 1.0 \mu \mathrm{M}$ ), indicating that the peptide has to accumulate at the surface for disruption.

\section{Live-Dead Assay Results and Time-Lapse Microscopy}

A

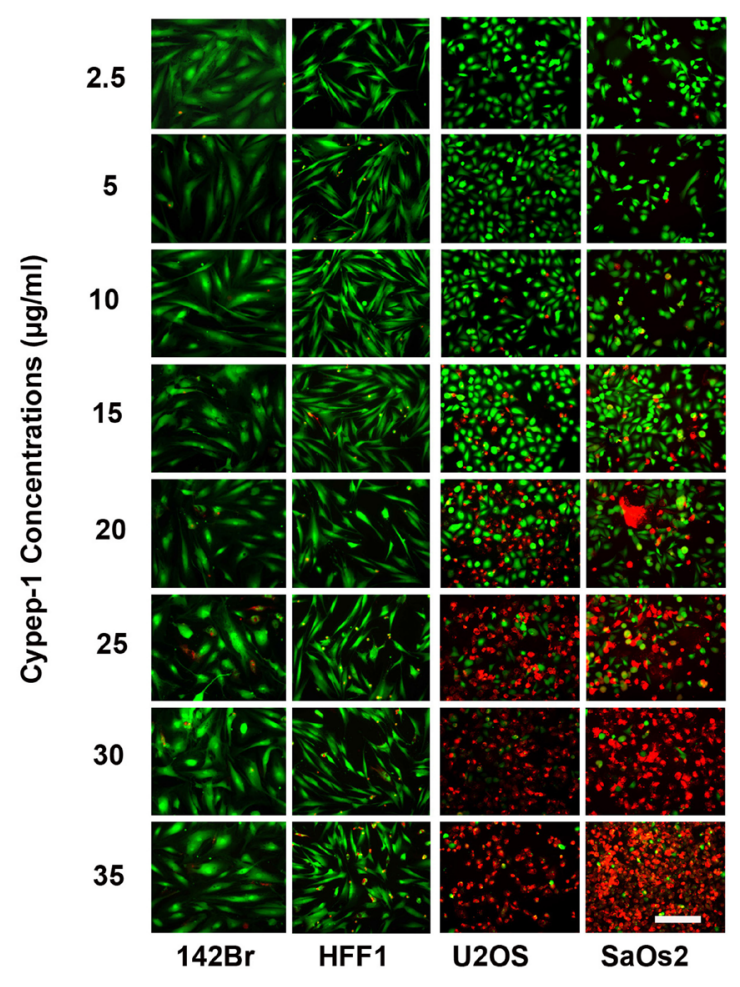

B Quantification of Live-Dead Assay Results

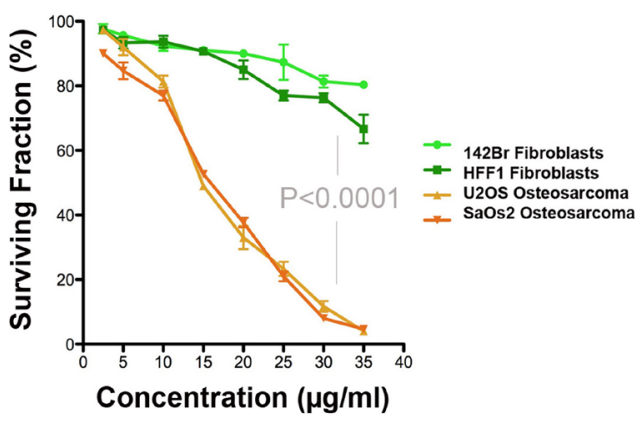

C Time Lapse Microscopy (20 $\mathrm{\mu g} / \mathrm{ml}$ of Cypep-1)

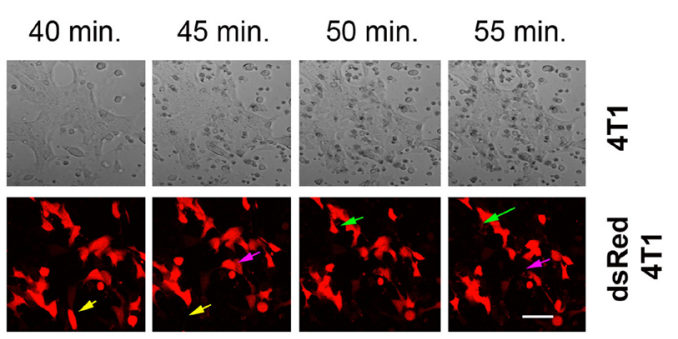

Figure 3: Effect of Cypep-1 on human osteosarcoma cell lines and normal human skin fibroblasts (142Br and HFF1). A) Representative images of cells treated with increasing concentrations for 3 hours. Green fluorescence (Calcein) indicates live cells and red (Ethidium homodimer-1) labels dead or dying cells. B) Dose-response curves based on the presence of Calcein. C) Time lapse microscopy of the mammary carcinoma cell line 4T1 treated with Cypep-1. 


\section{Plasma Activity, Bio Distribution and In Vivo Toxicity of Cypep-1}

\section{Radio Labelling of Cypep-1}

The elution pattern of ${ }^{125}$ I-labelled Cypep-1 corresponded to the small size and relative hydrophilicity of the peptide (27 amino acids, MW 3492.16), resembling closely that of unlabelled Cypep-1 as detected at UV 210 $\mathrm{nm}$ (data not shown).

\section{Plasma Activity and Bio Distribution}

The plasma activity of ${ }^{125}$ I-Cypep-1 declined rapidly over the course of $20 \mathrm{~min}$, the most dramatic drop occurring within the first $5 \mathrm{~min}$ following the i.v. tracer injection. Correspondingly, the plasma half-life of Cypep-1 was approx. 3.15 min (Fig. 5A).

As depicted in Fig. 5B the tissue distribution of Cypep-1 showed outstandingly high concentrations (* plasma space per $\mathrm{ml} / \mathrm{g}$ organ tissue wet weight) in liver

A

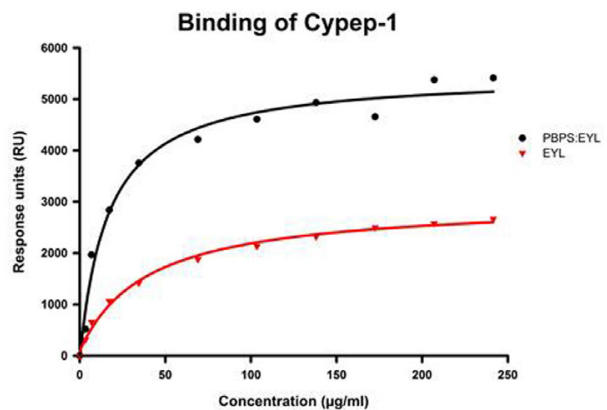

B

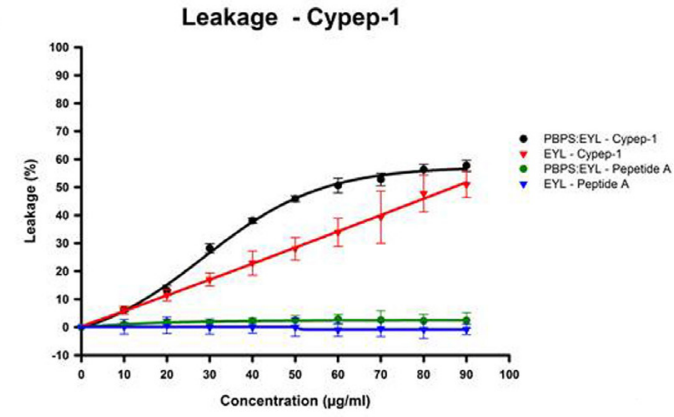

Figure 4: Quantification of Cypep-1s binding to negatively charged and neutral liposomes. A) Surface plasmon resonance demonstrates a significantly higher affinity of Cypep-1 to negatively charged PBPS: EYL liposomes (blue) than to neutral EYL liposomes (green). B) Quantification of vesicle leakage of negatively charged PBPS: EYL (blue) and neutral EYL (green) liposomes in the presence of by Cypep-1 (circle) and the control peptide (triangle).
$(11.74 *)$, spleen $(4.89 *)$ and kidneys $\left(1.685^{*}\right.$ per kidney). Comparatively low concentrations were found in the lungs $\left(0.38^{*}\right)$, stomach $(0.04 *)$, jejunum $\left(0.17^{*}\right)$, colon $\left(0.14^{*}\right)$ and muscle tissue $\left(0.02^{*}\right)$. Similarly, a low bio distribution value was obtained for the thyroid gland $(0.13 *)$. Very low concentrations of Cypep-1 were measured within the organs of the central nervous system, e.g. cerebellum $(0.00 *)$, cerebrum $(0.01 *)$ and eye $(0.02 *)$.

\section{In Vivo Toxicity}

Cypep-1 was slowly administered into the tail vein of $37 \mathrm{BALB} / \mathrm{c}$ mice at increasing doses from 50 to 800 $\mu \mathrm{g}$ Cypep-1 per $100 \mu 1$ bolus per animal (Fig. 5C). At Cypep-1 concentrations up to $500 \mu \mathrm{g}$, no signs of distress or pain were found in the experimental animals. The first signs of toxicity were observed at concentrations of 600 $\mu \mathrm{g}$ of Cypep-1, whereby the affected animals fell into a seizure-like catatonic stupor immediately after peptide administration. The first 5-10 min post Cypep-1 injection then proved to be decisive: Some experimental animals recovered within this period of time (after doses up to $700 \mu \mathrm{g}$ Cypep-1) and then continued to behave normally, while those that died, first began to show signs of laboured breathing, which then exacerbated and finally lead to death within the same period of time ( $5-10 \mathrm{~min}$ after the i.v. injection (maximum)).

The detailed autopsies following all cases of lethal toxicity revealed no macroscopic changes or anomalies. Thus, neither hints as to a possible mechanism of systemic toxicity of Cypep-1 for doses higher than $600 \mu \mathrm{g}(24 \mathrm{mg} /$ $\mathrm{kg}$ body weight), nor evidence as to the actual cause of death upon exposure to lethal doses of $800 \mu \mathrm{g}(32 \mathrm{mg} / \mathrm{kg}$ body weight) could be obtained. Other than the seizurelike catatonic stupor described above, the experimental animals showed no further signs of distress, pain or potential toxic effects after administration of Cypep-1. During the continuous observation period of the first 2 hours post injection, the mice (even the ones that had presented with severe signs of catatonic stupor before, but had recovered) continued their habitual behaviour, without any signs of discomfort, stress or pain. Further check-ups at $4 \mathrm{~h}, 6 \mathrm{~h}, 12 \mathrm{~h}$ and $24 \mathrm{~h}$ post Cypep-1 injection again showed mice at normal activity levels in accordance with their day/ night rhythm.

\section{Treatment of 4T1 Murine Breast Cancer Allografts}

As shown in Fig. 6A, all experimental animals were subjected to intratumoural injections at day 12 post-tumour inoculation, when the tumours of both study groups had reached an average volume of $0.12 \mathrm{~cm}^{3}$. The animals of the treatment group received a single intra-tumoural injection of $1200 \mu \mathrm{g}$ of Cypep-1 dissolved in $300 \mu 10.9 \% \mathrm{NaCl}$, 
while the animals of the control group were administered a similar injection volume of $0.9 \% \mathrm{NaCl}$. None of the animals showed any signs of discomfort, pain or toxicity after the respective injections. Again, once recovered from the Isofluoran anaesthesia, they all continued their habitual behaviour at normal activity levels.

At day 24, a significant reduction in tumour growth was observed in the tumours of the treatment group with an average volume of $1.1 \mathrm{~cm}^{3}$, whereas the control tumours had grown to an average size of $3.5 \mathrm{~cm}^{3}(\mathrm{P}<0.0001)$. The survival analyses (Fig. 6B) showed that the animals assigned to the treatment group lived significantly longer (median survival 32 days) than those of the control group (median survival 20 days) $(\mathrm{P}<0.0011)$.

Histological analysis of the untreated control tumours revealed a uniform tumour mass with no evidence of necrosis. The tumour cells had an atypical cell appearance and were densely packed with numerous mitotic figures (Fig 6C; left panel). In contrast, the tumours in the treatment group had extensive areas of necrosis at 24 hours after intra-tumoural Cypep-1 administration. Especially the border zone between viable and necrotic tissue contained large areas of pyknotic cells, characterized by an irreversible condensation of chromatin in the nucleus (Fig 6C; right panel).

\section{DISCUSSION}

In this study, we designed a proteolytically stable cationic lytic peptide of $27 \mathrm{D}$-amino-acids, designated Cypep-1, which showed a strong cytotoxic effect on a large panel of tumour cell lines, while affecting normal human fibroblasts to a significantly lesser extent.

SEM micrographs revealed numerous holes in the plasma membrane of 4T1 mammary carcinoma cells already after $60 \mathrm{~min}$ exposure to $35 \mu \mathrm{g} / \mathrm{ml}$ Cypep-1, while a subsequent total disintegration of the cell membrane occurred after 6 hours (Fig. 1C-F). This hole forming capacity has been described earlier for the AMPs Magainin and Dermaseptin S4, where it was named "toroidal pore" or "wormhole model" [52-56]. It has been viewed as a possible early step prior to the collapse of the membrane in the context of the "carpet model" mechanism, a common mechanism of action of many AMPs, whereby they assemble on the outer membrane surface of their target, forming "a carpet", until their local concentration is sufficient to increase the curvature strain on the target membrane to the point of formation of local "toroidal pores" $[12,55,57]$. These membrane perforations are thought to facilitate the passage of low molecular weight molecules prior to complete membrane lysis [16, 30]. The formation of microvilli and filopodia, as seen in the
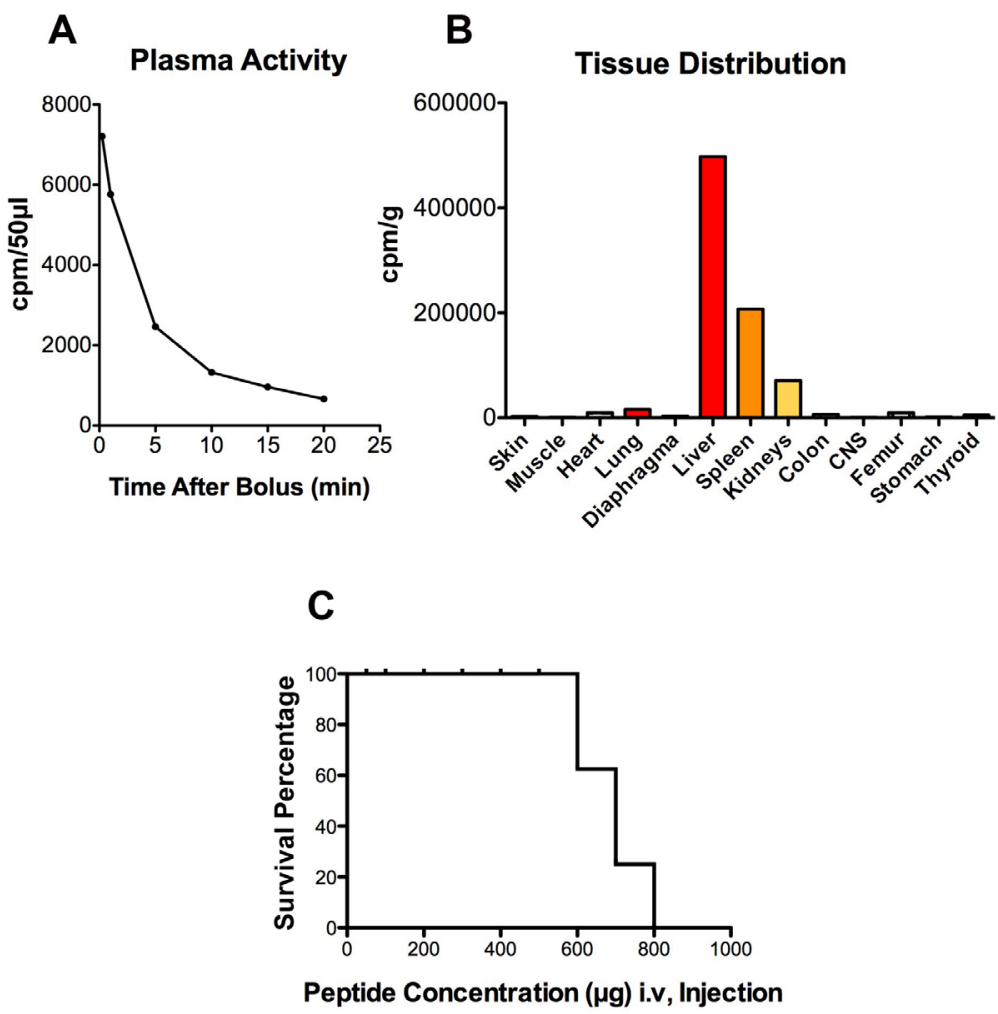

Figure 5: Pharmakokinetics, tissue distribution and toxicity after intravenous injection of ${ }^{125} \mathrm{I}-\mathrm{labelled}$ Cypep-1. A) Plasma clearance after bolus injection of $50 \mu \mathrm{g}$ of Cypep-1. B) Tissue Distribution of Cypep-1 20 min after administration C) In Vivo toxicity. 
untreated U87 cells (Fig. 1.A-B) may also add to the susceptibility towards Cypep-1 [47].

The membranolytic effect of Cypep-1 was confirmed by time-lapse confocal microscopy, where exposure of 4T1 and dsRed4T1 murine mammary carcinoma cells to Cypep-1 resulted in extensive membrane leakage (Fig. 3C; Suppl. Films 1 and 2).

SPR experiments (Fig. 4A), as well as liposome leakage assays (Fig. 4B) on negatively charged and neutral liposomes [30, 58], showed that Cypep-1 bound to both types of liposomes. Although its affinity to negatively charged vesicles was significantly higher, these results were slightly unexpected in view of Cypep-1's high isoelectric point ( $\mathrm{pI}=11.81)$ and the generally low affinity of AMPs towards the zwitterionic neutral membranes of normal cells. However, similar observations have been reported. Both Dermaseptin S4 [59] and human-like Cecropin LL-37 [60] were found to have a strong binding affinity and permeation capability for both zwitterionic and negatively charged phospholipid vesicles. Likewise was their relatively high affinity towards zwitterionic PC phospholipid membranes deemed surprising given their high positive net charge. This was explained in both cases by a possible interaction of the respective hydrophobic $\mathrm{N}$-termini of the peptides with the hydrophobic parts of the neutral zwitterionic phospholipids on the membrane surface of their targets, suggesting that a bundling of such interactions could initiate the binding of the respective peptides also to membrane of neutral net charge [30].

In sum, these findings are in line with the "carpet model" for membrane disruption, which was first proposed to describe the mode of action of Dermaseptin S4 [58] and later on that of many other AMPs [56, 59, 61-67].

The dose dependent cytotoxic effect of Cypep-1 was demonstrated in vitro for the concentration range of 2.5 to $35 \mu \mathrm{g}$ Cypep- $1 / \mathrm{ml}$, using two different cell viability assays. However, our results obtained using the LIVE/ DEAD assay (Fig. 3A and B) indicated a much wider therapeutic window, showing considerably higher cell survival rates for the human fibroblasts (142Br (human skin) and HFF1 (human foreskin)) and even lower survival rates in the osteosarcoma cell lines (U2OS and SaOs2) than the corresponding MTT results (Fig. 2A and B; Suppl. Fig. 2). Both cell assays measure the metabolism in intact cells. In case of the MTT proliferation assay, the applied Thiazolyl Blue Tetrazolium Bromide is metabolized only by viable cells, resulting in the formation of MTTFormazan crystals, which are then solubilised in acidified isopropanol and immediately measured at $570 \mathrm{~nm}$ by means of a microplate reader.
A

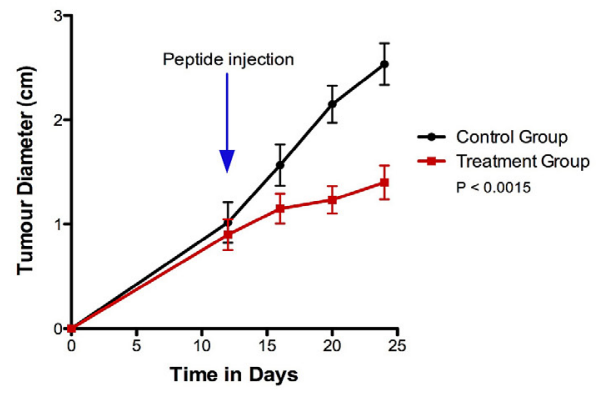

C

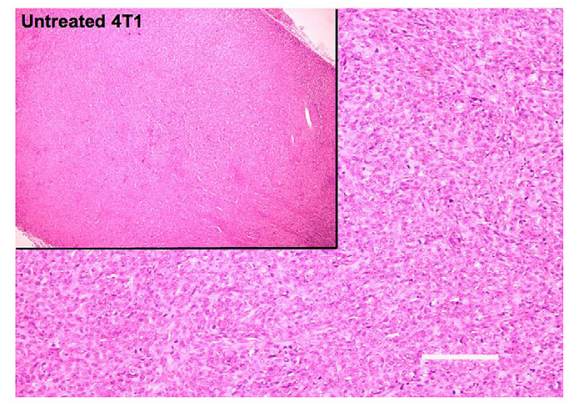

$\mathbf{B}$
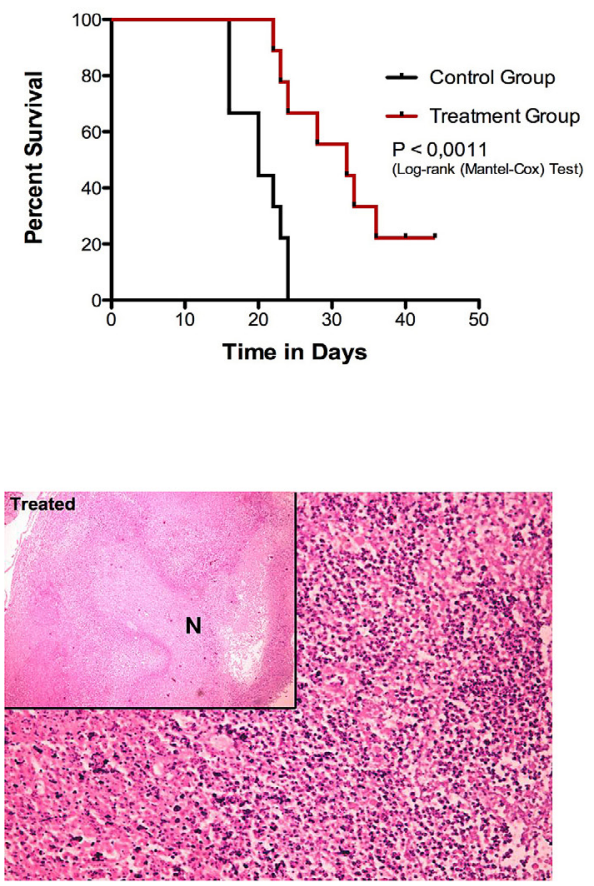

Figure 6: Treatment of 4T1 murine breast cancer allografts with Cypep-1. A) A single intratumoral injection of $1200 \mu \mathrm{g}$ Cypep-1 significantly reduced tumour growth $(\mathrm{P}<0.0001)$ and $\mathrm{B}$ ) increased survival in the treated animals compared to the control group $(\mathrm{P}<0.0011)$. C) Representative histology from untreated (left) and treated (right) tumors showed extensive areas of necrosis in the treatment group. 
The LIVE/DEAD assay contains Calcein-AM and Ethidium-Homodimer-1 and thus stains both live and dead cells simultaneously. Viable cells are able to convert non-fluorescent Calcein-AM into green fluorescent Calcein enzymatically due to the ubiquituous presence of intracellular esterase activity, whereas the red fluorescent Ethidium-Homodimer-1 is excluded by their intact cell membranes. Thus, the penetration of EthidiumHomodimer-1 indicates a loss of plasma membrane integrity, staining dead and dying cells. We therefore conclude that, in view of their membranolytic mode of action, the LIVE/DEAD assay may provide a more accurate and sensitive method for the evaluation of cell death induced by cytolytic peptides.

The biodistribution of ${ }^{125}$ I-labelled Cypep-1 showed a rapid initial plasma clearance, as may be expected due to the fast distribution within the extracellular space of a small 27 amino acids molecule (Fig. 5A). Its subsequent slower plasma clearance reflected both its removal due to glomerular filtration and tubular degradation [68], as well as its high uptake into the reticuloendothelial system (Fig. 5B). Correspondingly, Cypep-1 was found to have a short plasma half-life (approx. $3.5 \mathrm{~min}$ ). In contrast, hardly any accumulation was found in the lungs, organs of the gastro-intestinal tract, muscle tissue (Fig. 5B). This suggests that Cypep-1 is probably not suited for systemic administration in its present form. Still, one might try to exploit the pronounced retention of Cypep-1 in the liver and spleen to possibly achieve an oncolytic effect against localized cancers in these organs.

The low biodistribution value for the thyroid gland $(0.13 *)$ reflected the absence of free ${ }^{125} \mathrm{I}$-labelled iodine, thus being in line with the reverse phase chromatography results. Very low concentrations found within the organs of the central nervous system indicated that Cypep-1 did not pass the blood-brain-barrier (Fig. 5B).

Detailed autopsies were unable to disclose a possible mechanism of systemic toxicity, such as haemorrhaging or organ failure. Likewise, the reason for the seizures due to toxic doses remains unknown. In view of the strong evidence that Cypep-1 did not pass the blood-brainbarrier, it seems highly unlikely that these seizures could have been provoked by the penetration of Cypep- 1 into the central nervous system. However, given its cationic nature, the quick onset of signs of toxicity and thus provoked changes in the breathing pattern of the affected animals may possibly point towards a shift in the electrolyte pattern. This should clearly be explored further.

Achieving suitability for overall systemic use of Cypep-1 in the future would probably entail modifications of the present peptide. However, inspiration might be drawn from peptide studies of other groups, e.g. the creation of chimeric peptides, linkage to known receptorligands [69], hormone ligands [70, 71] or other nano carriers, as previously done with Melittin [72, 73].

To assess the effect of Cypep-1 on solid tumours in vivo, we injected the peptide locally into 4T1 murine mammary carcinoma allografts. A significant inhibition of tumour growth was achieved (Fig. 6A), resulting in large areas of severe necrosis (Fig. 6C) within the treated tumours (Fig. 6C). This increased the survival of the treated animals (Fig. 6B) significantly and there were no signs of systemic toxicity. This suggests that Cypep-1 in its present form appears to be well suited for local treatment of solid tumours.

In conclusion, we have designed a novel cytolytic peptide that shows a strong cytotoxic effect in vitro against various cancer cell lines. Functional studies using both cell lines and artificial model membranes, indicate that its effect is caused primarily by its interaction with negatively charged plasma membranes. Evidence suggests that Cypep-1 first accumulates on the membrane of its target, where it induces the formation of holes within the first 30 min upon application, while ultimately leading to its total disintegration within 6 hours. These findings support the "carpet model" of membrane disruption as its mechanism of action. However, it still remains to be investigated whether Cypep-1 may possible have any pro-apoptotic and/or anti-angiogenic effects.

Cypep-1's relative selectivity towards cancer cells, apparent proteolytic stability and low systemic toxicity suggest a considerable therapeutic potential.

Given its substantial local anti-tumoural effects on solid tumours in vivo, we believe that Cypep-1 should be exploited further for local administration against solid tumours.

\section{MATERIALS AND METHODS}

\section{Peptide Design and Production}

The initial peptide library was designed in silico with respect to the identification of active sites of tumours suppressors and oncogenes by combining bioinformatic softwares provided by Expasy and the data base UniProtKB/Swiss-Prot, which are both available online $[51,74]$. The sizes of the resulting in silico peptides varied from 10 to 30 amino acids. In order to facilitate their cellular internalisation, a TAT-HIV sequence was attached to the C-terminal ends. All peptides were C-terminal acetylated and $\mathrm{N}$-terminal amidated. The peptide library was produced by Cambridge Peptides (Cambridge, UK). The peptides were then screened with the MTT (3-(4,5-dimethylthiazol-2-yl)-2,5-diphenyltetrazolium bromide) assay on U87 human glioma cells. Cellular morphology after peptide exposure was assessed by crystal violet staining and light microscopy. All experiments were performed in triplicate.

The peptide with the most potent activity was then selected for further analysis. To increase the stability of 
the peptide, two further sub-formulations of the original formula (L-aa, containing only L-amino acids) were created: D-aa (retro inversed, (ri)), a peptide comprised of a backward sequence of the original in silico formula, yet made up solely of D-amino acids and an analogue peptide to original in silico peptide formula, comprised of D-amino acids. D-amino acids are highly resistant to protease mediated degradation and have a low immunogenic response. The respective peptide variants were tested in the following concentrations: 7.5, 10, 15,20 and $25 \mu \mathrm{g} / \mathrm{ml}$ and incubated for 3 hours. The activity (at a concentration of $15 \mu \mathrm{g} / \mathrm{ml}$ ) of the most potent of these three peptide variants was verified again after an incubation time of 3 hours by means of light microscopy. This novel cationic peptide of 27 amino acids (YGRKKRRQRRRGKTLRVAKAIYKRYIE) was then selected for larger scale synthesis, performed by GenScript (Piscataway, NJ, USA).

\section{Scanning Electron Microscopy (SEM)}

4T1 mammary carcinoma cells growing on coverglass slides were exposed to $35 \mu \mathrm{g} / \mathrm{ml}$ Cypep- 1 for 60 minutes and for 6 hours, respectively. Thereafter, the slides were prepared for SEM as originally described by Anderson [75]. After mounting them on stubs with tape and silver paint, an approximately $50 \mathrm{~nm}$ thick gold layer was evaporated on the specimens, using a Polaron E5000 SEM Coating Unit (Polaron Components Ltd, Watford, UK). Finally, the specimens were examined with a Jeol JSM-7400F scanning electron microscope (Jeol Ltd, Tokyo, Japan).

\section{Cell Lines and Cell Culture}

Cypep-1 was tested in various concentrations on a total of 17 cell lines, which included 13 human and 1 murine tumour cell line(s), as well as 3 normal human cell lines. Listed in detail: 4 human osteosarcoma (U2OS, SaOS2, HOS and MNNG-HOS), 6 human glioblastoma (A172, GaMg [76], LN18, U87, U373 and T98G) and 3 human mammary carcinoma cell lines (MCF7, AU565 and MDA-MB-468) as well as an additional murine mammary carcinoma cell line (4T1). Furthermore, 3 normal human cell lines were included: 2 normal human fibroblast cell lines (HFF1 and 142Br) as well as normal human osteoblasts (HOB).

The tumour cell lines were obtained from the American Type Culture Collection (ATCC, Rockville, MA), with the exception of GaMg, which had originally been established at the University of Bergen (Department of Biomedicine, Bergen, Norway) [76].

All cell lines used were DNA fingerprinted by short tandem repeat (STR) analysis.

Most cell lines were grown in Dulbecco's Modified
Eagle's Medium (DMEM; Sigma-Aldrich, St. Louis, MO), supplemented with $10 \%$ foetal calf serum (FCS; PAA Laboratories GmbH, Pasching, Austria), 2\% L-glutamine (Cambrex, East Rutherford, NJ), four times the prescribed concentration of non-essential amino acids (NEAA 100x; Cambrex, East Rutherford, NJ), and the antibiotics Penicillin (100 U/ml) and Streptomycin (100 mg/ml (PEN-STREPTM; 5000U Penicillin/ml and 5000 $\mu \mathrm{g}$ Streptomycin/ml; Cambrex, East Rutherford, NJ), as well as Plasmocin ${ }^{\mathrm{TM}}$ (25mg/ml; Invivogen, San Diego, CA).

All normal human cell lines were purchased from Promo Cell (Heidelberg, Germany). While the normal human foreskin fibroblasts (HFF1) were grown in DMEM medium as described above, the additional human skin fibroblast cell line $(142 \mathrm{Br})$ and the normal human osteoblasts (HOB) were cultured in purchased cell type specific growth mediums (Promo Cell, Heidelberg, Germany).

All cell lines were kept in a standard tissue culture incubator at $37^{\circ} \mathrm{C}$ and $5 \% \mathrm{CO}_{2}$ in $75 \mathrm{~cm}^{2}$ tissue culture flasks (Nunc TM, Roskilde, Denmark). They were passaged at approx. 80\% confluence and allowed a settling period of 24 hours before the start of the respective experiments.

\section{Cell Viability Assays}

The in vitro cytotoxicity of Cypep-1 was measured by the MTT proliferation assays and a LIVE/DEAD Viability/ Cytotoxicity assay kit (Molecular Probes, Invitrogen, Invitrogen Dynal AS, Oslo, Norway).

\section{MTT Proliferation Assays}

MTT proliferation assays were performed on all cell lines (with the exception of 142Br (human skin fibroblasts)), using monolayers of 15000 cells in sterile 96 well tissue culture plates (Nunc ${ }^{\text {TM }}$, Roskilde, Denmark), respectively. All cells were incubated with Cypep-1 dissolved in $0.9 \% \mathrm{NaCl}$, at the following concentrations: $0.1,0.5,1.0,5,10,15,20,25,30$ and $35 \mu \mathrm{g}$ of Cypep-1 per $\mathrm{ml}$ and assayed after 15, 30, 45, 60, 75, 90, 180, 270 and $360 \mathrm{~min}$.

\section{LIVE/DEAD Viability/Cytotoxicity Assays}

In order to visualise and quantify the cytotoxic action of Cypep-1 simultaneously, the LIVE/DEAD ${ }^{\circledR}$ Viability/Cytotoxicity Kit was employed according to the manufacturers instructions on monolayers of 30000 cells in sterile 24 multi well dishes (Nunc ${ }^{\mathrm{TM}}$, Roskilde, Denmark), using the selected human osteosarcoma cell lines U2OS and SaOs2 as well as the two human fibroblast cell lines HFF1 (foreskin) and 142Br (skin).

The monolayer cultures were incubated with 
Cypep-1 for a period of 3 hours in concentrations ranging from $2.5 \mu \mathrm{g}$ to $35 \mu \mathrm{g} / \mathrm{ml}$. The cells were observed using an inverted fluorescence microscope (Nikon Eclipse 2000E, Tokyo, Japan) equipped with FITC (green fluorescence) and TRITC (red fluorescence) filter optics. The fluorescent cells were then photographed at a 10x magnification. The proportions of viable cells (live cells showing green fluorescence due to the presence of Calcein) and dead cells (red fluorescent due to the membrane penetration of Ethidium-Homodimer-1) were quantified using a Lucia G Morphometry System, Version 4.71 (Laboratory Imaging, Prague, Czech Republic).

\section{Time Lapse Confocal Microscopy}

30.000 cells of the murine mammary carcinoma cell line 4T1 were seeded into a sterile 24 well dish ( $\mathrm{Nunc}^{\mathrm{TM}}$, Roskilde, Denmark). After 24 hours, the monolayer culture was treated with $20 \mu \mathrm{g}$ Cypep- $1 / \mathrm{ml}$, followed by immediate observation of the cells at $37^{\circ} \mathrm{C}$ and $5 \% \mathrm{CO}_{2}$ for a period of 3 hours by means of time-lapse confocal microscopy, using a Zeiss LSM510 Meta System (Carl Zeiss AG, Jena, Germany), equipped with both bright field optics and red fluorescence optics at $595 \mathrm{~nm}$. The same experiment was repeated as described above with 4T1 cells that had previously been stably transfected with red fluorescent protein, using a dsRed-expressing lentiviral vector $\mathrm{pWPXL}$-dsRED as previously described by Niclou et al. [77].

\section{Interactions of Cypep-1 with Biological Model Membranes}

Structural and mechanistic insights on the interaction of Cypep-1 with biological model membranes were obtained by surface plasmon resonance (SPR) and liposome-content leakage assays monitored by fluorescence spectroscopy.

\section{Surface Plasmon Resonance (SPR) Experiments}

SPR was used to quantify the binding of Cypep-1 to phospholipid model membranes of different compositions at neutral $\mathrm{pH}(\mathrm{pH} 7.4)$ and a temperature of $25^{\circ} \mathrm{C} .100 \mathrm{~nm}$ liposomes made of egg yolk lysolecithin (EYL; L- $\alpha$-phosphatidylcholine; 95\% purity) were employed to represent amphitropic, neutral membranes, while liposomes composed of both pig brain L- $\alpha$ phosphatidylserine (PBPS) and EYL (from Avanti Polar Lipids Inc., Alabaster, Alabama, USA), with PBPS:EYL in a 1:1 $\mathrm{M}$ : $\mathrm{M}$ mixture, represented acidic, negatively charged membranes. Both liposome type mixtures have been found to properly represent the fluidity of biologically relevant membranes [78] [79]. The SPR analyses were carried out on a BIAcore 3000 instrument (BIAcore AB, Uppsala, Sweden) as described in Halskau et al. [80], using a L1 sensor chip from BIAcore (BIAcore AB, Uppsala, Sweden).

\section{Liposome Leakage Assays}

To assess the membranolytic effect of Cypep- 1 on the integrity of phospholipid model membranes, liposome leakage assays monitored by fluorescence spectroscopy were performed on $200 \mathrm{~nm}$ liposomes as described earlier $[81,82]$. A 18 -residue peptide that shows a low interaction with membranes[82] (purchased from CPC Scientific, San Jose, CA) was used as control in the leakage assays (Peptide A).

Negatively charged PBPS: EYL (1:1 mixture) as well as neutral pure EYL vesicles were used, in which both liposome types encapsulated the fluorochrome ANTS (8 aminonaphtalene-1,3,6 trisulfonic acid) and its corresponding quencher DPX (p-xylene-bis[N-pyridinium bromide]). In principle, a disruption of the liposomes' bi-layer induces leakage of the fluorophore ANTS. This entails an increase in fluorescence at $510 \mathrm{~nm}$. All fluorescence spectra were recorded at $25^{\circ} \mathrm{C}$ and $\mathrm{pH} 7.4$ on a Cary Eclipse Fluorescence Spectrophotometer (Varian Optical Spectroscopy Instruments, Mulgrave, Victoria, Australia). The respective titrations with Cypep-1 and the control Peptide A were performed in concentrations ranging from $0 \mu \mathrm{g} / \mathrm{ml}$ to $90 \mu \mathrm{g} / \mathrm{ml}(0 \mu \mathrm{M}$ to $26 \mu \mathrm{M})$. The fluorescence was measured for each concentration point of the concentration series, and all measurements were performed in triplicate. At the end of each measurement, Triton X-100 was added to a final concentration of $2 \mathrm{mM}$, to obtain the maximum membrane leakage. The resulting maximum fluorescence at $510 \mathrm{~nm}$ is defined as $100 \%$, i.e. complete liposome breakdown. The induced leakages of the fluorophore ANTS due to exposure to the peptides were then evaluated as a percentage of its complete release after Triton X-100 exposure. The initial fluorescence intensity of the respective liposome solutions was defined as $0 \%$ leakage.

\section{Plasma Activity, Bio Distribution and In Vivo Toxicity of Cypep-1}

\section{Radio Labelling of Cypep-1}

The radio labelling of Cypep-1 was performed with ${ }^{125} \mathrm{I}$, according to the Iodo-Gen method as described by Fraker et al. [83]. The obtained ${ }^{125} \mathrm{I}$-Cypep-1 stock solution was stored in the dark at $4^{\circ} \mathrm{C}$ for 48 hours prior to validation by reversed phase chromatography, using a $4.6 \times 50$ mm Dionex Proswift RP-2H column on an Ettan 
LC System (GE Healthcare, Oslo, Norway) in line with a Radiomatic 610TR Flow System Analyzer by Perkin Elmer (PerkinElmer, Waltham, MA) for gamma detection.

\section{Plasma Activity and Biodistribution of Cypep-1}

The plasma activity and biodistribution of ${ }^{125}$ I-Cypep-1 was evaluated in a single experiment. An adult female Wistar rat of $260 \mathrm{~g}$ body weight was anaesthetized using $15 \mathrm{mg}$ of Pentobarbital i.p.. Its body temperature was maintained at $37^{\circ} \mathrm{C}$, using both a heating pad and an infrared lamp. Two PE-50 polyethylene catheters were placed into the femoral vein for the bolus injection of Cypep-1 and one into the femoral artery for blood sampling. $50 \mu 1$ of the ${ }^{125}$ I-Cypep-1 stock solution dissolved in $500 \mu 10.9 \% \mathrm{NaCl}$ were injected i.v., and a total of six arterial blood samples (100 $\mu$ l per sample) were collected at $0.25,1,5,10,15$ and 20 min following the ${ }^{125} \mathrm{I}$-Cypep-1 administration. The animal was sacrificed under deep anaesthesia with an i.v. bolus injection of 0.5 $\mathrm{ml}$ saturated $\mathrm{KCl}$. The tissue and plasma samples were harvested immediately and counted for ${ }^{125}$ I-activity in a gamma-counter (LKB Wallac 1285, Turku, Finland). The peptide distribution volumes in the various body tissues were calculated as the ${ }^{125}$ I-activity per gram tissue sample divided by the time-averaged plasma ${ }^{125}$ I-activity during the 20 minutes clearance period $(*=$ plasma equivalent space in $\mathrm{ml} / \mathrm{g}$ tissue wet weight).

\section{In Vivo Toxicity of Cypep-1}

Cypep-1 was injected into the lateral tail vein of $37 \mathrm{BALB} / \mathrm{c}$ mice (average age 131,7 days; average weight $25.2 \mathrm{~g}$ ). In detail, the group consisted of 18 male (average weight $26.5 \mathrm{~g}$ ) and 19 female animals (average weight $23.9 \mathrm{~g}$ ). The respective peptide concentrations administered were increased systematically from $50 \mu \mathrm{g}$ up to $800 \mu \mathrm{g}$ Cypep-1 per bolus per animal. All Cypep-1 doses were adjusted to a total injection volume of $100 \mu \mathrm{l}$ $0,9 \% \mathrm{NaCl}$, which remained constant for all animals. Throughout the experiment, a group of 4 animals ( 2 males/ 2 females) received the same Cypep-1 concentrations per bolus, respectively. All injections were performed very slowly in order to avoid cardiac stress. The mice were then observed for a period of $24 \mathrm{~h}$ with regards to signs of distress and pain (e.g. orbital tightening, flattened ear position, formation of nose and/or cheek bulge, whisker change, overall activity level) as well as potential toxic effects. During the first 2 hours, the animals were monitored continuously and then checked again at $4 \mathrm{~h}, 6$ $\mathrm{h}, 12 \mathrm{~h}$ and $24 \mathrm{~h}$ post injection.

\section{Treatment of Subcutaneous 4T1 Metastatic Breast Cancer Allografts}

$10^{6} 4 \mathrm{~T} 1$ murine metastatic breast cancer cells were grafted subcutaneously under Isofluran anaesthesia into the right upper quadrant of the back of 20 female BALB/c mice (average age 126,25 days; average weight $23.8 \mathrm{~g}$ ). At day 12 , when the tumours of both groups had reached a tumour volume of $0.12 \mathrm{~cm}^{3}$ in average, 10 female mice (average weight $23.9 \mathrm{~g}$ ) received a single intra-tumoural injection of $1200 \mu \mathrm{g}$ of Cypep-1 dissolved in $300 \mu 10.9 \%$ $\mathrm{NaCl}$, whereas an equal injection volume of $0.9 \% \mathrm{NaCl}$ was administered to the 10 animals of the control group (average weight $23.7 \mathrm{~g}$ ). All injections were performed under isofluoran gas anaesthesia. The animals were then observed for signs of distress as described above. 24 hours after the injections, two animals (one assigned to the control and one of the treatment group) were sacrificed for histological analysis. The harvested tumours were immediately fixed in $4 \%$ buffered formaldehyde and embedded in paraffin, cut into $5 \mu \mathrm{m}$ sections and stained with H\&E.

In the remaining 18 experimental animals, the tumour size was measured at regular intervals (every $4^{\text {th }}$ day) until day 24 post tumour grafting. All mice were monitored daily for signs of distress and pain. Those that became sick were euthanized humanely. All animal procedures described were in accordance with protocols approved by The National Animal Research Authority (Oslo, Norway).

\section{Statistical analyses}

Statistical analyses were performed using Prism software. Comparisons between groups were performed using one-way analysis of variance (ANOVA). For the analysis of the Kaplan-Meier a log-rank (Mantel-Cox) test was used. $\mathrm{P}<0.05$ was considered significant.

\section{ACKNOWLEDGEMENTS}

This project was supported by the Norwegian Cancer Society, the Norwegian Research Council, Innovest AS, Helse Vest, Haukeland University Hospital, as well as the Bergen Medical Research Foundation.

\section{Conflict of interest}

Lars Prestegarden holds a patent on CyPep-1

\section{REFERENCES}

1. Hancock RE, Diamond G: The role of cationic antimicrobial peptides in innate host defences. Trends Microbiol 
$2000 ; 8: 402-410$

2. van 't Hof W, Veerman EC, Helmerhorst EJ, Amerongen AV: Antimicrobial peptides: Properties and applicability. Biol Chem 2001;382:597-619.

3. Zasloff M: Antimicrobial peptides of multicellular organisms. Nature 2002;415:389-395.

4. Boman HG: Antibacterial peptides: Basic facts and emerging concepts. J Intern Med 2003;254:197-215.

5. Ganz T: Defensins: Antimicrobial peptides of innate immunity. Nat Rev Immunol 2003;3:710-720.

6. Eliassen LT, Berge G, Sveinbjornsson B, Svendsen JS, Vorland LH, Rekdal O: Evidence for a direct antitumor mechanism of action of bovine lactoferricin. Anticancer Res 2002;22:2703-2710.

7. Leuschner C, Hansel W: Membrane disrupting lytic peptides for cancer treatments. Curr Pharm Des 2004;10:2299-2310.

8. Hancock RE, Sahl HG: Antimicrobial and host-defense peptides as new anti-infective therapeutic strategies. Nat Biotechnol 2006;24:1551-1557.

9. Brown KL, Hancock RE: Cationic host defense (antimicrobial) peptides. Curr Opin Immunol 2006;18:2430.

10. Lehmann J, Retz M, Sidhu SS, Suttmann H, Sell M, Paulsen F, Harder J, Unteregger G, Stockle M: Antitumor activity of the antimicrobial peptide magainin ii against bladder cancer cell lines. Eur Urol 2006;50:141-147.

11. Papo N, Seger D, Makovitzki A, Kalchenko V, Eshhar Z, Degani H, Shai Y: Inhibition of tumor growth and elimination of multiple metastases in human prostate and breast xenografts by systemic inoculation of a host defenselike lytic peptide. Cancer Res 2006;66:5371-5378.

12. Hoskin DW, Ramamoorthy A: Studies on anticancer activities of antimicrobial peptides. Biochim Biophys Acta 2008;1778:357-375.

13. Makovitzki A, Fink A, Shai Y: Suppression of human solid tumor growth in mice by intratumor and systemic inoculation of histidine-rich and ph-dependent host defenselike lytic peptides. Cancer Res 2009;69:3458-3463.

14. Fadnes B, Rekdal O, Uhlin-Hansen L: The anticancer activity of lytic peptides is inhibited by heparan sulfate on the surface of the tumor cells. BMC Cancer 2009;9:183.

15. Epand RM, Vogel HJ: Diversity of antimicrobial peptides and their mechanisms of action. Biochim Biophys Acta 1999;1462:11-28.

16. Shai Y: Mode of action of membrane active antimicrobial peptides. Biopolymers 2002;66:236-248.

17. Hetru C, Letellier L, Oren Z, Hoffmann JA, Shai Y: Androctonin, a hydrophilic disulphide-bridged nonhaemolytic anti-microbial peptide: A plausible mode of action. Biochem J 2000;345 Pt 3:653-664.

18. Ellerby HM, Arap W, Ellerby LM, Kain R, Andrusiak R, Rio GD, Krajewski S, Lombardo CR, Rao R, Ruoslahti E, Bredesen DE, Pasqualini R: Anti-cancer activity of targeted pro-apoptotic peptides. Nat Med 1999;5:1032-1038.

19. Papo N, Shai Y: Host defense peptides as new weapons in cancer treatment. Cell Mol Life Sci 2005;62:784-790.

20. Mader JS, Hoskin DW: Cationic antimicrobial peptides as novel cytotoxic agents for cancer treatment. Expert Opin Investig Drugs 2006;15:933-946.

21. Johnstone SA, Gelmon K, Mayer LD, Hancock RE, Bally MB: In vitro characterization of the anticancer activity of membrane-active cationic peptides. I. Peptide-mediated cytotoxicity and peptide-enhanced cytotoxic activity of doxorubicin against wild-type and p-glycoprotein over-expressing tumor cell lines. Anticancer Drug Des 2000;15:151-160.

22. Ohsaki Y, Gazdar AF, Chen HC, Johnson BE: Antitumor activity of magainin analogues against human lung cancer cell lines. Cancer Res 1992;52:3534-3538.

23. Koczulla AR, Bals R: Antimicrobial peptides: Current status and therapeutic potential. Drugs 2003;63:389-406.

24. Steinstraesser L, Kraneburg UM, Hirsch T, Kesting M, Steinau HU, Jacobsen F, Al-Benna S: Host defense peptides as effector molecules of the innate immune response: A sledgehammer for drug resistance? Int J Mol Sci 2009;10:3951-3970.

25. Al-Benna S, Shai Y, Jacobsen F, Steinstraesser L: Oncolytic activities of host defense peptides. Int J Mol Sci 2011;12:8027-8051.

26. Zachowski A: Phospholipids in animal eukaryotic membranes: Transverse asymmetry and movement. Biochem J 1993;294 ( Pt 1):1-14.

27. Zwaal RFAaSAJ: Pathophysiologic implications of membrane phospholipid assymetry. Blood 1997;89:11211132.

28. Manno S, Takakuwa,Y. ,Mohandas, N.: Identification of a functional role for lipid asymmetry in biological membranes_ phosphatidylserine-skeletal protein interactions modulate membrane stability. PNAS 2002;99:1943-1948.

29. Utsugi T, Schroit AJ, Connor J, Bucana CD, Fidler IJ: Elevated expression of phosphatidylserine in the outer membrane leaflet of human tumor cells and recognition by activated human blood monocytes. Cancer Res 1991;51:3062-3066.

30. Shai Y: Mechanisms of the binding, insertion and destabilization of phospholipid bilayer membranes by $\alpha$-helical antimicrobial and cell non-selective membrane-lytic peptides. Biochimica et Biophysica Acta 1999;1462:55-70.

31. Dobrzynska I, Szachowicz-Petelska B, Sulkowski $\mathrm{S}$, Figaszewski Z: Changes in electric charge and phospholipids composition in human colorectal cancer cells. Mol Cell Biochem 2005;276:113-119.

32. Zwaal RF, Comfurius P, Bevers EM: Surface exposure of phosphatidylserine in pathological cells. Cell Mol Life Sci 2005;62:971-988. 
33. Dennison SR, Whittaker M, Harris F, Phoenix DA: Anticancer alpha-helical peptides and structure/function relationships underpinning their interactions with tumour cell membranes. Curr Protein Pept Sci 2006;7:487-499.

34. Iwasaki T, Ishibashi J, Tanaka H, Sato M, Asaoka A, Taylor D, Yamakawa M: Selective cancer cell cytotoxicity of enantiomeric 9-mer peptides derived from beetle defensins depends on negatively charged phosphatidylserine on the cell surface. Peptides 2009;30:660-668.

35. Rosenfeld Y, Lev,N.and Shai,Y.: Effect of the hydrophobicity to net positive charge ratio on antibacterial and anti-endotoxin activities of structurally similar antimicrobal peptides. Biochemistry 2010:853-861.

36. Hietanen E, et al.: Fatty acid composition of phospholipids and neutral lipids and lipid peroxidation in human breast cancer and lipoma tissue. Carcinogenesis 1986;7:19651969.

37. Sok M, Sentjurc M, Schara M: Membrane fluidity characteristics of human lung cancer. Cancer Lett 1999;139:215-220.

38. Kozlowska K, Nowak J, Kwiatkowski B, Cichorek M: Esr study of plasmatic membrane of the transplantable melanoma cells in relation to their biological properties. Exp Toxicol Pathol 1999;51:89-92.

39. Yoon WH, Park HD, Lim K, Hwang BD: Effect of o-glycosylated mucin on invasion and metastasis of $\mathrm{hm} 7$ human colon cancer cells. Biochem Biophys Res Commun 1996;222:694-699.

40. Burdick MD, Harris A, Reid CJ, Iwamura T, Hollingsworth MA: Oligosaccharides expressed on mucl produced by pancreatic and colon tumor cell lines. J Biol Chem 1997;272:24198-24202

41. Cappelli G, Paladini S, D'Agata A: [tumor markers in the diagnosis of pancreatic cancer]. Tumori 1999;85:S19-21.

42. Papo N, Shai Y: New lytic peptides based on the d,1amphipathic helix motif preferentially kill tumor cells compared to normal cells. Biochemistry 2003;42:93469354.

43. Kleeff J, Ishiwata T, Kumbasar A, Friess H, Buchler MW, Lander AD, Korc M: The cell-surface heparan sulfate proteoglycan glypican-1 regulates growth factor action in pancreatic carcinoma cells and is overexpressed in human pancreatic cancer. J Clin Invest 1998;102:1662-1673.

44. Salmivirta M, Safaiyan F, Prydz K, Andresen MS, Aryan M, Kolset SO: Differentiation-associated modulation of heparan sulfate structure and function in caco-2 colon carcinoma cells. Glycobiology 1998;8:1029-1036.

45. Burg MA, Pasqualini R, Arap W, Ruoslahti E, Stallcup WB: Ng2 proteoglycan-binding peptides target tumor neovasculature. Cancer Res 1999;59:2869-2874.

46. Matsuda K, Maruyama H, Guo F, Kleeff J, Itakura J, Matsumoto Y, Lander AD, Korc M: Glypican-1 is overexpressed in human breast cancer and modulates the mitogenic effects of multiple heparin-binding growth factors in breast cancer cells. Cancer Res 2001;61:55625569.

47. Chan SC, Hui L, Chen HM: Enhancement of the cytolytic effect of anti-bacterial cecropin by the microvilli of cancer cells. Anticancer Res 1998;18:4467-4474.

48. Bessalle R, Kapitkovsky A, Gorea A, Shalit I, Fridkin M: All-d-magainin: Chirality, antimicrobial activity and proteolytic resistance. FEBS Lett 1990;274:151-155.

49. Dathe M, Wieprecht T, Nikolenko H, Handel L, Maloy WL, MacDonald DL, Beyermann M, Bienert M: Hydrophobicity, hydrophobic moment and angle subtended by charged residues modulate antibacterial and haemolytic activity of amphipathic helical peptides. FEBS Lett 1997;403:208-212.

50. Wieprecht T, Dathe M, Krause E, Beyermann M, Maloy WL, MacDonald DL, Bienert M: Modulation of membrane activity of amphipathic, antibacterial peptides by slight modifications of the hydrophobic moment. FEBS Lett 1997;417:135-140.

51. ExPASy: Expasy bioinformatics resource portal wwwexpasyorg

52. Baker MA, Maloy WL, Zasloff M, Jacob LS: Anticancer efficacy of magainin2 and analogue peptides. Cancer Res 1993;53:3052-3057.

53. Matsuzaki K, Murase O, Fujii N, Miyajima K: Translocation of a channel-forming antimicrobial peptide, magainin 2 , across lipid bilayers by forming a pore. Biochemistry 1995;34:6521-6526.

54. Matsuzaki K, Murase O, Fujii N, Miyajima K: An antimicrobial peptide, magainin 2, induced rapid flip-flop of phospholipids coupled with pore formation and peptide translocation. Biochemistry 1996;35:11361-11368.

55. Matsuzaki K, Sugishita K, Ishibe N, Ueha M, Nakata S, Miyajima K, Epand RM: Relationship of membrane curvature to the formation of pores by magainin 2 . Biochemistry 1998;37:11856-11863.

56. Mor A, Nicolas P: The nh2-terminal alpha-helical domain 1-18 of dermaseptin is responsible for antimicrobial activity. J Biol Chem 1994;269:1934-1939.

57. Ludtke SJ, He K, Heller WT, Harroun TA, Yang L, Huang HW: Membrane pores induced by magainin. Biochemistry 1996;35:13723-13728.

58. Pouny Y, Rapaport D, Mor A, Nicolas P, Shai Y: Interaction of antimicrobial dermaseptin and its fluorescently labeled analogues with phospholipid membranes. Biochemistry 1992;31:12416-12423.

59. Ghosh JK, Shaool D, Guillaud P, Ciceron L, Mazier D, Kustanovich I, Shai Y, Mor A: Selective cytotoxicity of dermaseptin s3 toward intraerythrocytic plasmodium falciparum and the underlying molecular basis. J Biol Chem 1997;272:31609-31616.

60. Oren Z, Lerman JC, Gudmundsson GH, Agerberth B, Shai Y: Structure and organization of the human antimicrobial peptide 11-37 in phospholipid membranes: Relevance to the molecular basis for its non-cell-selective activity. Biochem 
J 1999;341 ( Pt 3):501-513.

61. Strahilevitz J, Mor A, Nicolas P, Shai Y: Spectrum of antimicrobial activity and assembly of dermaseptin-b and its precursor form in phospholipid membranes. Biochemistry 1994;33:10951-10960.

62. Gazit E, Boman A, Boman HG, Shai Y: Interaction of the mammalian antibacterial peptide cecropin p1 with phospholipid vesicles. Biochemistry 1995;34:11479-11488.

63. Shai Y: Molecular recognition between membrane-spanning polypeptides. Trends Biochem Sci 1995;20:460-464.

64. Shai Y, Oren Z: Diastereoisomers of cytolysins, a novel class of potent antibacterial peptides. J Biol Chem 1996;271:7305-7308.

65. Oren Z, Hong J, Shai Y: A repertoire of novel antibacterial diastereomeric peptides with selective cytolytic activity. J Biol Chem 1997;272:14643-14649.

66. Oren Z, Shai Y: Selective lysis of bacteria but not mammalian cells by diastereomers of melittin: Structurefunction study. Biochemistry 1997;36:1826-1835.

67. Wong H, Bowie JH, Carver JA: The solution structure and activity of caerin 1.1, an antimicrobial peptide from the australian green tree frog, litoria splendida. Eur J Biochem 1997;247:545-557.

68. Tenstad O, Williamson, H.E., Clausen,G., Øien, H.,Aukland,K.: Glomerular filtration and tubular absorption of the basic polypeptide aprotinin. Acta Physiol Scand 1994; 152:33-50.

69. Ellerby HM, Lee S, Ellerby LM, Chen S, Kiyota T, del Rio G, Sugihara G, Sun Y, Bredesen DE, Arap W, Pasqualini $\mathrm{R}$ : An artificially designed pore-forming protein with antitumor effects. J Biol Chem 2003;278:35311-35316.

70. Leuschner C, Enright FM, Melrose PA, Hansel W: Targeted destruction of androgen-sensitive and -insensitive prostate cancer cells and xenografts through luteinizing hormone receptors. Prostate 2001;46:116-125.

71. Leuschner C, Enright FM, Gawronska B, Hansel W: Membrane disrupting lytic peptide conjugates destroy hormone dependent and independent breast cancer cells in vitro and in vivo. Breast Cancer Res Treat 2003;78:17-27.

72. Soman NR, Lanza GM, Heuser JM, Schlesinger PH, Wickline SA: Synthesis and characterization of stable fluorocarbon nanostructures as drug delivery vehicles for cytolytic peptides. Nano Lett 2008;8:1131-1136.

73. Soman NR, Baldwin SL, Hu G, Marsh JN, Lanza GM, Heuser JE, Arbeit JM, Wickline SA, Schlesinger PH: Molecularly targeted nanocarriers deliver the cytolytic peptide melittin specifically to tumor cells in mice, reducing tumor growth. J Clin Invest 2009;119:2830-2842.

74. Swiss-Prot U: Uniprotkb/ swiss-prot. wwwuniprotorg

75. Anderson TF: Techniques for preservation of 3-dimensional structure in preparing specimens for electron microscopy. Trans NY Acad Sci 1951;13:130-133.

76. Akslen LA, Andersen, K.J., Bjerkvig, R.: Characteristics of human and rat glioma cells grown in a defined medium.
Anticancer Res 1988 8:797-803.

77. Niclou SP, Danzeisen,C., Eikesdal,H.P. , Wiig,H. ,Brons, N.H. , Poli, A.M, Svendsen,A. , Torsvik, A. , Enger, P.Ø., Terzis,J.A., Bjerkvig,R. : A novel egfp-expressing immunodeficient mouse model to study tumor-host interactions. FASEB J 2008;22:3120-3128

78. Singer SJaN, G. L.: The fluid mosaic model of the structure of cell membranes Science 1972;175:720-731.

79 Luckey M: Membrane structural biology: With biochemical and biophysical foundations. 2008: Cambridge Univ Pr $2008 ; 344$.

80. Halskau O, Ying, M., Baumann, A., Kleppe, R., RodriguezLarrea, D., Almas, B., Haavik, J., and Martinez, A. (2009) Three-way Interaction between 14-3-3 Proteins, the N-terminal Region of Tyrosine Hydroxylase, and Negatively Charged Membranes Three-way interaction between 14-3-3 proteins, the n-terminal region of tyrosine hydroxylase, and negatively charged membranes. J Biol Chem 2009;284:32758-32769.

81. Mossberg AK, Puchades, M., Halskau, O., Baumann, A., Lanekoff, I., Chao, Y., Martinez, A., Svanborg, C., and Karlsson, R. : Hamlet interacts with lipid membranes and perturbs their structure and integrity. PLoS ONE 2010;5

82. Baumann A, Gjerde AU, Ying M, Svanborg C, Holmsen H, Glomm WR, Martinez A, Halskau O: Hamlet forms annular oligomers when deposited with phospholipid monolayers. Journal of molecular biology 2012;418:90-102.

83. Fraker P, and Speck JC, Jr. : Protein and cell membrane iodinations with a sparingly soluble chloroamide, 1,3,4,6-tetrachloro-3a,6a-diphrenylglycoluril. Biochem Biophys Res Commun 1978;80:849-857. 